\title{
Health \& Nutrition in Primary Schools of Hajin Town of District Bandipora in J \& K (A Study)
}

\author{
Tariq Ahmad Guroo \\ Political Science Research Scholar \\ Barkatullah University \\ India
}

\begin{abstract}
ABSTRACT: The present research paper is concerned with the health \& nutrition in primary school, and throws light on some aspect related with the primary school going students and their health and nutrition's. The main purpose of this working is to describe the major issues of Health \& Nutrition in primary schools and to identify some important challenges for Health \& Nutrition in primary institutions in Hajin town of district Bandipora of $J \& K$. The findings of this study show that Health \& Nutrition in primary schools of Hajin town continue to remain overwhelmed by ample problems, which affect their performance in the efficient discharge of their growth and qualities which is inimical to their academic achievements. The increased problem of ailments/infections among school children due to poor personal hygiene practices and malnutrition conditions remains a concern on the public health agenda in Kashmir. Health is a key factor in school entry. School is the place where health education regarding important aspects of hygiene, environment and nutrition, as well as social customs, is being instructed. The teacher is the guardian as well as Spiritual parent of the child in school and plays a crucial role in the whole process of primordial prevention. Poor knowledge and practice of and attitudes towards personal hygiene and nutrition plays a major roles in the high occurrence of stagnation on development and growth, therefore has negative consequences for a child's long term overall development School Achievements as well.
\end{abstract}

KEYWORDS: Health, Nutrition, primary schools, Hajin town \& academic achievements.

\section{INTRODUCTION}

In an educational world filled with failing schools and indifferent students, state boards of education have searched for answers on how to increase test scores and create school systems where all students receive the best education possible. Amongst the plethora of possible solutions, perhaps they should look first at the nutritional substance of what our school-aged children are eating each day as they struggle through a day of learning. There is an association between nutrition and cognition as well as psychosocial behaviour; this link has been highly under-researched, but there exists many studies that look at the nutritional benefits of many proteins, vitamins, and food stuffs as they affect learning and brain function. Our schools have the potential to play a vigorous role in preparing and nourishing our students' potential learning capabilities and benefitting their social behaviours by bringing up nutritious breakfasts and lunches during school timing in school days. Providing the nation's low-income youth with nutritious food has been a concern for over a hundred years. To see that food insufficient students were adequately fed, school lunch programs began during the Great Depression of the 1930's. From the beginning the program had two goals: to make use of surplus agricultural commodities owned by the government as a result of price-support agreement with the farmers and to help prevent nutritional deficiencies among low-income school children by feeding them nutritious meals. On June 4, 1946 President Truman signed an act known as the National School Lunch Program (NSLP). This was in response to claims that had been made that many American men were rejected from WWII military service due to diet-related health problems. The federally assisted meal 
program was created to safeguard the health and well-being of the nation's children and to encourage the consumption of American-grown commodities. The federal government would reimburse schools for student who qualified for free or reduced meals. Students who didn't qualify were able to purchase lunch, and their money was used to off-set the costs of building new facilities for the expanding program. The program started to expand because of the increasing number of women working outside the home during the war $^{\text {(Winchell, 2009). }}$

\section{Knowledge and Practice of Personal Hygiene among Primary School Students:}

The increased burden of communicable diseases among school children due to poor personal hygiene practices and inadequate sanitary conditions remains a concern on the public health agenda in developing countries $^{\text {(Murray CJL, Lopez AD. , 1996.) }}$. School children are particularly vulnerable to neglect of basic personal hygiene due lack of knowledge and practice (Vivas A, 2010). Poor knowledge, practice of and attitudes to personal hygiene such as hand washing play major roles in the high incidence of communicable diseases and therefore has negative consequences for a child's long term overall development ${ }^{(\mathrm{M} ., 2013)}$. Improved awareness and hand hygiene practices especially among children have effectively reduced gastrointestinal and respiratory tract infections by up to $50 \%$ the two leading causes of childhood morbidity and mortality around the world (Luby SP, 2005). In addition, studies have also shown that school children with better knowledge and practices of personal hygiene have fewer sick days and absenteeism in school and achieve higher grades (Water and Sanitation Program Can hygiene be cool and fun: Insights from School Children in Senegal. ). School is the place where health education regarding important aspects of hygiene, environment and sanitation, as well as

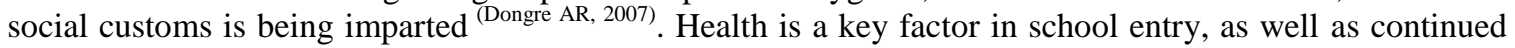
participation and attainment in school. The teacher is the guardian of the child in school and plays a pivotal

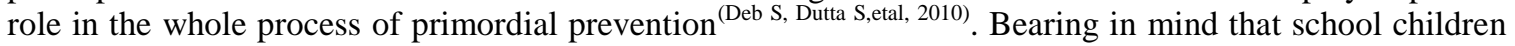
have been consistently implicated in the spread of communicable diseases and that the school has been recognized as a vital setting for health promotion (R.B., 2008.), this study was planned to assess personal hygiene in primary school children in Sharjah, United Arab Emirates. The aim of this study was to investigate existing knowledge and practices related to personal hygiene among primary school children between grade 1 and 5 . The results from the study will help to understand the factors influencing the personal hygiene behaviours in primary school children and to overcome barriers in acquisition of proper knowledge and practices.

\section{Personal Hygiene Perception among School Students:}

Children's wellbeing is important in its own right (United Nations, 1989) . It can affect the physical health of the children and determines how well they do at school ${ }^{\text {(Zullig et al, 2005) }}$ and correspondingly their future. Hygiene which means cleanliness is defined by World Health Organisation as" conditions and practices that helps to maintain health and prevent the spread of diseases" (Nations, 2014). Also, it refers to the science that deals with the promotion and preservation of health (medical dictionary). Hygiene is a set of forms practiced and performed to preserve human health. Personal Hygiene defined as keeping the body, clothing and the surrounding (whether inside or outside home) clean and away from microbes to maintain health and cease the spread of diseases ${ }^{\text {(Rasool, } 2012)}$ Hence, personal hygiene serves two main objectives. First; it keeps the person healthy and prevents catching or spreading the diseases via him. Second; it helps in keeping good mentality, by feeling good in concern to self and body. The talk about keeping good hygiene thoroughly and on regular basis should include also the home and the surrounding as a whole not only the body. It is an overall cleanliness. The child's health belongs mainly to his body and his environment and this will decide if he is safe or vulnerable to get diseases and correspondingly damaged health. Personal hygiene perception and practice varies from country to another. This depends mainly upon habits, cultures, resources, genders, standard of living and level of education. And at the same time all agree at the main purpose of personal hygiene is to keep bacteria, viruses and fungus away from human bodies. Being dirty, body, clothes and surrounding will make the person under the attack of microorganisms and be unacceptable and suffer from discrimination which leads to physical, mental and social problems and eventually death. There are specific sets of norms of hygiene applicable in every country. The Problem of the human body and its capability of providing good places for disease-causing microorganisms to grow and multiply. These places are represented by skin of the whole body and in and around the openings of the body. Important aspect of selfcare is proper hygiene practices. Although techniques are basic, there are still many people who do not practice it properly. Usually, school age child (6-12 years) is in close contact with floor ${ }^{\text {(Feigelman, 2011). }}$ His hands are in touch with everything surrounds him. Caregiver (body and clothes), toys and also peers in the 
class room with whom he shares things without thinking of the importance of hygiene are main sources of getting dirt and germs. Moreover, relationships with peers and the physical environment of school are also associated with students' life satisfaction (Lindberg L, Swanberg I, 2006). He doesn't have the understanding of how the infectious diseases spread and how can by decreased by practicing certain norms of hygiene and how to make self-esteem high. The later comes from being clean and tidy.

\section{Nutritional status and related factors:}

The health well-being of children is a fundamental issue in education. Indeed, active promotion of health is now seen as a priority for school. The level of concern is illustrated by the fact that WHO has set up a global school health initiative. In countries around the world, the issue is being addressed through school health services, health education and school meals programmers ${ }^{\mathrm{i}}$.

Good nutrition is of prime important in the attainment of normal growth and development and in the maintenance of health throughout life. Especially in their early life, the children need adequate and appropriate quality of food to meet the nutrient requirement for their physical and mental growth and development.

Malnutrition is widespread problem and affects large number of people in developing countries. Vulnerable population like school children are susceptible to health problems associated with micronutrient deficiencies. Malnutrition has deleterious effects on the brain structure of the children. Malnourished children have smaller brain size and fewer cells than nourished one $\mathrm{e}^{\mathrm{ii}}$ and malnutrition lowers the children's resistance to disease: resulting in high morbidity and mortality among young children. Malnutrition lowered vitality of the people leading to lowered productivity and reduced life expectancy.

The middle childhood, 6 to 12 years old, is a period of steady physical growth. The average gain in weight during this period is about 3 to $3.5 \mathrm{~kg}$ per year and in height approximately $6 \mathrm{~cm}$ added each year ${ }^{\text {iii. }}$. This age is also the period of major cognitive development. Their brain reaches nearly adult size by the end of primary- school age during this period, life pattern and habits are established and it will become the ground where the quality of life it going to be ground. A school child is one of the vulnerable groups to malnutrition and health problems related with nutrient deficiencies. Improving the health of school children become a policy priority in international health school feeding program is one of the way because if they have malnutrition its can be influence in concentration of study and decrease of ability in success of study ${ }^{\text {iv }}$.

School-based programs can play an important role in promoting lifelong healthy eating. Because dietary factors "contribute substantially to the burden of preventable illness and premature death in the United States," the national health promotion and disease prevention objectives encourage schools to provide nutrition education from preschool through 12th grade $\mathrm{v}$. The U.S. Department of Agriculture's (USDA) Nutrition Education and Training (NET) Program urges "nutrition education \{to\} be a major educational component of all child nutrition programs and offered in all schools, child care facilities, and summer sites" by the year $2000^{\mathrm{vi}}$. Because diet influences the potential for learning as well as health, an objective of the first national education goal is that children "receive the nutrition and health care needed to arrive at school with healthy minds and bodies ${ }^{\text {vii }}$.

\section{Significance:}

School children are particularly vulnerable to neglect of basic personal hygiene.Healthy eating patterns in childhood and adolescence promote optimal childhood health, growth, and intellectual development; prevent immediate health problems, such as iron deficiency anaemia, obesity, eating disorders, and dental caries; and may prevent long-term health problems, such as coronary heart disease, cancer, and stroke. School health programs can help children and adolescents attain full educational potential and good health by providing them with the skills, social support, and environmental reinforcement they need to adopt longterm, healthy eating behaviours. 


\section{Research Question:}

What is nutritional status and related factors among elementary school children in Hajin town of Bandipora District of Kashmir valley?

\section{Hypotheses:}

$\mathrm{H}_{\mathrm{o}}$ : There is significant relationship between health and nutrition with academic potential and mental growth.

$\mathrm{H}_{\mathrm{o}}$ : Elementary Schooling plays a vital role in good health habits and nutritional food.

\section{Objectives:}

The general objectives of the study were to identify health \& nutritional status \& also related factor among elementary school in educational zone of district Bandipora of Kashmir valley

\section{Specific Objectives:}

1. To assess the nutritional status among elementary school children.

2. To describe the predisposing factors (Socio demographic factor included Grade of class, Gender, Age, Birth order, towards the health nutrition and attitude towards nutrition)

\section{Operational Definition:}

1. Elementary school children: refers to student age $\leq 8$ to 14 years old who attend grade $3^{\text {rd }}$ to $8^{\text {th }}$ in public elementary school at educational Zone Bandipora, district Bandipora of Kashmir valley.

2. Health: refers to a state of complete physical, mental and social well-being.

3. Nutritional status: refers to the physical of child in weight and height.

\section{Area of study and research methodology:}

AREA OF STUDY Jammu \& Kashmir is northern-most Indian Administered state (IAK), lying between six mountain ranges and covering an area of 2, 22,236 sq. kilometers. It is located between $32^{\circ} 17^{\prime}$ and $36^{\circ} 58^{\prime}$ North latitude, and between $37^{\circ} 26^{\prime}$ and $80^{\circ} 30^{\prime}$ East longitude ${ }^{\text {viii. }}$. It is average height of about 6,000 feet above the sea; it is approximately eight-four miles in length, and twenty to twenty-five mile in breath $^{(\text {Lawrence, }}{ }^{1895)}$. The region commonly known as Kashmir is bounded on the north by Afghanistan and China, on the east by China, on the south by the state of Himachal Pradesh and the state of Punjab in India, and on the west by the North-West Frontier Province and the Punjab Province of Pakistan. Jammu and Kashmir actually comprises of three regions: the foothill plains of Jammu; the lakes and valleys of Kashmir with high altitude plains and mountains of Ladakh which lies beyond narrow passes ${ }^{\text {ix }}$. 


\section{Map: 1-Hajin Town}

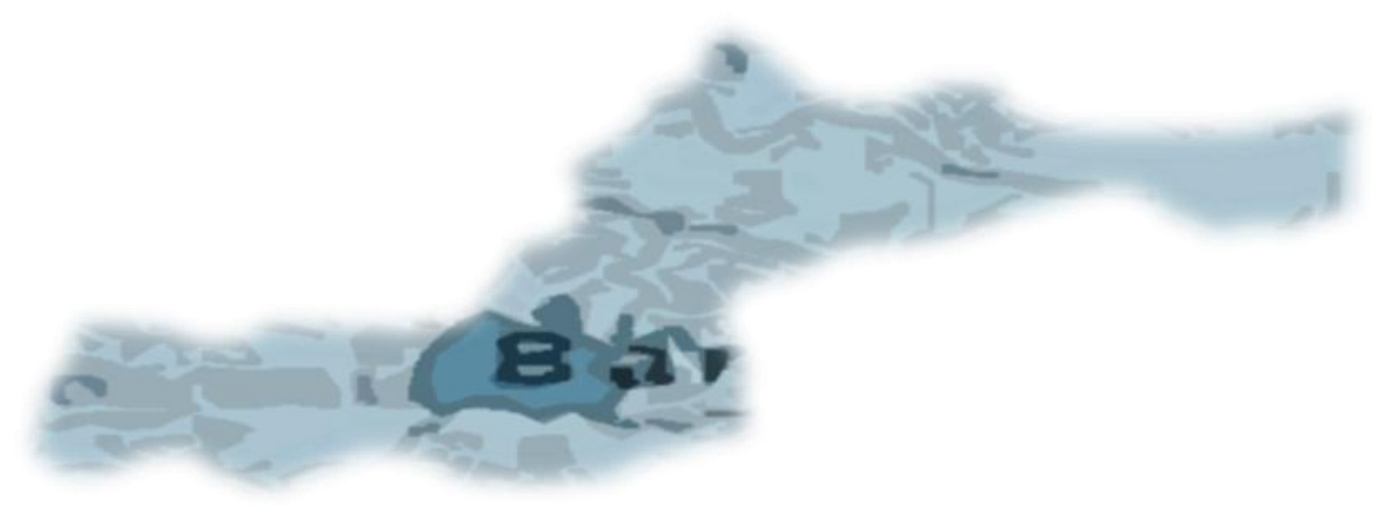

\section{Historical Background of Town Hajin:}

In the North - West of Kashmir, with a population of 12000, a low-lying bowl shaped town exists in the left basin of river Jhelum at a distance of $37 \mathrm{Kms}$ from Srinagar.

Hajin is an alternative Tehsil in Bandipora District; it is newly carved Tehsil from erstwhile Sonawari Tehsil. In its east the town of Sumbal at a distance of $8 \mathrm{Kms}$, in the North - West the lake of Wular and in the South town Sopore at a distance of $15 \mathrm{Kms}$ make a dummy border. The town with a rural look is surrounded by dimensions and dense plain forests containing Popular and Willow trees besides huge grasslands usually called Rakhs.

\section{Materials \& Methodology:}

As the approach followed in most social science research, present study is based on the both primary as well as secondary source of the data collection.

\section{Methodology:}

Design of study:

This study was descriptive cross sectional study to study nutritional status among elementary school children in district Bandipora.

\section{Population:}

The target population of this study was elementary schools students' age between 6 to 14 year's old group (level 4, 5, 6, 7 \& 8 standards) elementary school children in district Bandipora of Kashmir valley.

\section{Sample:}

A descriptive study was conducted in district Bandipora of Kashmir valley. It is carried out on the sixth to forth-teen year students, for genders, males and females, at elementary schools to assess the perception of personal hygiene and nutritious food among them. Zone one of education was chosen randomly in Bandipora. Ten schools were chosen by clusters sampling from this zone. Five elementary schools for males and another five for females were taken. Ten students from each school were chosen randomly, so the total sample were (100) students. The total of (50) males and (50) females were the subjects of this study. 
Table Frequency distribution of respondents Socio Demography Factors:

\begin{tabular}{|c|c|}
\hline Socio Demography factor & $\mathrm{n}=100$ \\
\hline \multicolumn{2}{|c|}{ Grade of class } \\
\hline Grade 3-4 & 26 \\
\hline Grade 5-6 & 33 \\
\hline Grade 7-8 & 41 \\
\hline Total & 100 \\
\hline \multicolumn{2}{|c|}{ Gender } \\
\hline Male & 50 \\
\hline Female & 50 \\
\hline Total & 100 \\
\hline \multicolumn{2}{|c|}{ Age } \\
\hline$<10$ & 21 \\
\hline 11 & 22 \\
\hline 12 & 47 \\
\hline$>12$ & 10 \\
\hline Total & 100 \\
\hline \multicolumn{2}{|c|}{ Order by Birth } \\
\hline 1st Birth & 26 \\
\hline 2nd Birth & 30 \\
\hline$>2$ nd Birth & 44 \\
\hline Total & 100 \\
\hline \multicolumn{2}{|c|}{ Snacking Habit (DAILY) } \\
\hline 1st time & 39 \\
\hline Twice Bandipora & 35 \\
\hline More than Thrice & 26 \\
\hline Total & 100 \\
\hline
\end{tabular}




\begin{tabular}{|c|c|}
\hline \multicolumn{2}{|c|}{ Money for snacking (DAILY in rupees) } \\
\hline Ten to Twenty & 7 \\
\hline twenty to Forty & 78 \\
\hline$>$ Forty & 15 \\
\hline Total & 100 \\
\hline
\end{tabular}

The above table represents that majority of the respondents (41\%) were Grade 7-8, following by Grade 5 6 and Grade $3-4$. The proportions of male and female respondents were equal (50 each). Most of the respondents are belong to age group of twelve years (47\%), and the mean average of age bar was 8.78 years old with SD of 0.1.551. Majority of the respondents $44 \%$ was more than second child of their family, only $26 \%$ was the first child and rest $30 \%$ was the second born child.

Most of the respondent (39\%) took snaking 1 time per day. 35\% take 2 times daily and rest $26 \%$ spent money for snacks more than three times per day. The most of the respondent spent between 20-40 rupees per day for buying snack. The mean of money for buying snacking per day was 31.2 and SD was 10.721.

Table-1: Distribution of the respondents/children according to the demographical data.

\begin{tabular}{|c|c|c|c|}
\hline $\begin{array}{l}\text { Demography Characteristic of the } \\
\text { child }\end{array}$ & Groups & Frequencies & Percentage \\
\hline \multirow{4}{*}{ Age in Years } & $10-12$ & 12 & 12 \\
\hline & $<11-12$ & 52 & 52 \\
\hline & $<12-13$ & 4 & 4 \\
\hline & $<13-14$ & & \\
\hline \multicolumn{2}{|l|}{$\mathrm{N}=100$} & 100 & 100 \\
\hline \multirow[b]{2}{*}{ Gender } & Male & 50 & 50 \\
\hline & Female & 50 & 50 \\
\hline \multicolumn{2}{|l|}{$\mathrm{N}=100$} & 100 & 100 \\
\hline \multirow[b]{2}{*}{ Child's level of education } & 3 rd to 5 th & 50 & 50 \\
\hline & 6th to 8th & 50 & 50 \\
\hline \multicolumn{2}{|l|}{$\mathrm{N}=100$} & 100 & 100 \\
\hline & Illiterate & 4 & 4 \\
\hline & Read \& Write & 31 & 31 \\
\hline & Intermediate & 16 & 16 \\
\hline
\end{tabular}




\begin{tabular}{|c|c|c|c|}
\hline \multirow[t]{2}{*}{ Father's level of education } & High School & 23 & 23 \\
\hline & $\begin{array}{l}\text { College or } \\
\text { More }\end{array}$ & 26 & 26 \\
\hline \multicolumn{2}{|l|}{$\mathrm{N}=100$} & 100 & 100 \\
\hline \multirow[b]{5}{*}{ Mother's level of education } & Illiterate & 5 & 5 \\
\hline & Read \& Write & 23 & 23 \\
\hline & Intermediate & 34 & 34 \\
\hline & High School & 19 & 19 \\
\hline & $\begin{array}{l}\text { College or } \\
\text { More }\end{array}$ & 19 & 19 \\
\hline \multicolumn{2}{|l|}{$\mathrm{N}=100$} & 100 & 100 \\
\hline \multirow{3}{*}{ Number of children in family } & $1-3$ & 45 & 45 \\
\hline & $4-6$ & 43 & 43 \\
\hline & $<8$ & 12 & 12 \\
\hline \multicolumn{2}{|l|}{$\mathrm{N}=100$} & 100 & 100 \\
\hline \multirow{3}{*}{ Child order in family } & $<2$ nd & 12 & 12 \\
\hline & 3rd to 5 th & 45 & 45 \\
\hline & 6th to 8 th & 43 & 43 \\
\hline \multicolumn{2}{|l|}{$\mathrm{N}=100$} & 100 & 100 \\
\hline \multirow[t]{3}{*}{ Family Income } & Adequate & 59 & 59 \\
\hline & $\begin{array}{l}\text { Relatively } \\
\text { Adequate }\end{array}$ & 36 & 36 \\
\hline & Inadequate & 5 & 5 \\
\hline \multicolumn{2}{|l|}{$\mathrm{N}=100$} & 100 & 100 \\
\hline
\end{tabular}

The table number 1 , shows that the age of children is ranging between age $<11-12(52 \%)$ and the age $<12$ $13(32 \%)$. The cumulative percentage is $(84 \%)$. For the gender and year of study, the researcher chooses them identically. Only (4\%) of fathers are illiterate and (5\%) of mothers are also, while the fathers and mothers who can read and write comprise $(31 \%)$ and $(23 \%)$ from the sample's parents respectively. The majority of mothers are intermediate level graduates (34\%), while the college's graduates comprise the higher ratio for the fathers (26\%). As seen in the table, most of the families have from 1-3 children (55\%) and comes second (31\%) the families who have 4-6 children. Also (34\%) of the families, their children 
whom taken in the study are the 1 st born. A total of (59\%) of the income reviewed as adequate $(<500000-$ 1000000 ID).

\section{Analysis:}

This study was conducted in one of the educational zone of district Bandipora in Kashmir valley. One hundred (100) students which 6 to 14 years old who attended to the class $3^{\text {rd }}$ to $8^{\text {th }}$ at elementary school, Bandipora Municipal council were collected. The respondents were interviewed by interview schedule.

Table-2Frequency distribution of students' Knowledge Level about the health \& nutrition at children:

\begin{tabular}{|l|l|l|l|l|l|l|}
\hline Knowledge Level & \multicolumn{2}{|c|}{ Male } & \multicolumn{2}{c|}{ Female } & \multicolumn{2}{c|}{ Total } \\
& \multicolumn{2}{|c|}{$(\mathrm{n}=50)$} & & \multicolumn{2}{c|}{$(\mathrm{n}=100)$} \\
\cline { 2 - 8 } & $\mathrm{n}$ & $\%$ & $\mathrm{n}$ & $\%$ & $\mathrm{n}$ & $\%$ \\
\hline Good (>80\%) & 17 & 8.5 & 18 & 9 & 35 & 35 \\
\hline Fair (60\% to 80\%) & 23 & 11.5 & 20 & 10 & 43 & 43 \\
\hline Poor (<60\%) & $10 \quad 5$ & 12 & 6 & 22 & 22 \\
\hline Mean=72.76, SD=14.83, Min=10 \& max=98 & & & & & \\
\hline
\end{tabular}

The knowledge on health and nutrition was categorized into three groups, good (>80\%), fair $(60-80 \%)$ and poor $(<60 \%)$. The percentage of score was range from minimum 0 to maximum 18 . The above table shows the level of knowledge was found among 35\% of respondents, fair level $43 \%$ and poor level $22 . \%$ the mean scores was 72.76 with SD of 14.83 with minimum score 10 and maximum score 98 among total respondents.

Table-3Frequency distributions of students' correct answer of Knowledge Level about the health \& nutrition by item analysis:

\begin{tabular}{|r|l|r|}
\hline & $\begin{array}{l}\text { Frequency distribution Of attitude towards nutrition An } \\
\text { item analysis }\end{array}$ & Correct \\
\hline S.No. & knowledge items & \\
\hline 1 & \multicolumn{1}{|c|}{ Reflection of health? } & \\
\hline 1.1 & Has appropriate weight for age. & \\
\hline 1.2 & Gain weight every month. & \\
\hline 1.3 & Active \& do supports. & 97 \\
\hline 1.4 & Had good appetite. & 99 \\
\hline
\end{tabular}




\begin{tabular}{|c|c|c|}
\hline 1.5 & Rarely ill. & 98 \\
\hline 2 & \multicolumn{2}{|l|}{ Meaning of nutritious food? } \\
\hline 2.1 & Contain vitamins & 89 \\
\hline 2.2 & healthy food 5 excellent & 88 \\
\hline 2.3 & healthy \& clean foods & 82 \\
\hline 2.4 & Fruits \& Vegetable & 89 \\
\hline 3 & The main nutrient in rice is carbohydrate & 72 \\
\hline 4 & Food contain protein resource & 72 \\
\hline 5 & food contain vitamin resource & 15 \\
\hline 6 & The main nutrient in oil is fat & 79 \\
\hline 7 & Eating a wide variety of vegetables regularly & 67 \\
\hline 8 & Fast food like fried chicken have high cholesterol & 59 \\
\hline 9 & Main nutrient in biscuits is carbohydrate & 87 \\
\hline 10 & Main nutrient in milk & 74 \\
\hline 11 & Main nutrient in green vegetable & 66 \\
\hline
\end{tabular}

Frequency distribution of knowledge by question items showed that nearly $90 \%$ of respondents knew the meaning nutrition food. Most of the respondent (87\% round-up) knew that main nutrient in biscuits is carbohydrate. The low rate 10\% (round-up) of correct answer was found in the statement that food contain vitamin resource.

Table-4Frequency distribution of attitude towards nutrition by item an analysis:

\begin{tabular}{|l|l|l|l|l|l|l|}
\hline \multicolumn{2}{|l|}{ Frequency distribution of attitude towards nutrition by item an analysis. (N=100) } \\
\hline $\begin{array}{l}\text { Attitude Statement } \\
\dot{\Sigma}\end{array}$ & $\begin{array}{l}\text { Fast food like fried chicken is good to eat } \\
\text { every day }\end{array}$ & 24 & 36 & 22 & 10 & 7 \\
\hline 1 & $\begin{array}{l}\text { I usually consider nutrition when I choose } \\
\text { food }\end{array}$ & 3 & 7 & 20 & 33 & 37 \\
\hline 3 & Important for my good health to enjoy eating & 2 & 12 & 23 & 24 & 39 \\
\hline
\end{tabular}




\begin{tabular}{|c|c|c|c|c|c|c|}
\hline & variety of food & & & & & \\
\hline 4 & $\begin{array}{l}\text { I am willing to cut down on foods that are not } \\
\text { good for me }\end{array}$ & 10 & 12 & 9 & 25 & 44 \\
\hline 5 & I am conscious effort to try drinking milk & 14 & 7 & 9 & 30 & 52 \\
\hline 6 & $\begin{array}{l}\text { it is important for my good health to eat } 2 \\
\text { meals }\end{array}$ & 2 & 4 & 17 & 41 & 36 \\
\hline 7 & $\begin{array}{l}\text { I like homemade foods better than food in } \\
\text { restaurants }\end{array}$ & 83 & 7 & 19 & 32 & 41 \\
\hline 8 & Eat health is just another fashion & 24 & 35 & 24 & 11 & 7 \\
\hline 9 & I do not need make changes to my diet & 3 & 5 & 25 & 32 & 35 \\
\hline 10 & it is important to eat adequate amount of rice & 6 & 3 & 20 & 38 & 33 \\
\hline 11 & I eat more when II am bored or unhappy & 28 & 31 & 28 & 10 & 3 \\
\hline 12 & I like to reward myself with food & 36 & 29 & 19 & 7 & 5 \\
\hline 13 & I think thin is beautiful & 41 & 24 & 18 & 12 & 9 \\
\hline 14 & I like trying new and unusual foods & 41 & 15 & 21 & 12 & 12 \\
\hline 15 & $\begin{array}{l}\text { We can eat Instant noodle every day \& can } \\
\text { make health }\end{array}$ & 38 & 18 & 12 & 17 & 15 \\
\hline
\end{tabular}

Note: $\mathrm{SD}=$ strongly disagree, $\mathrm{D}=$ dis-agree, $\mathrm{UN}=$ undecided, $\mathrm{A}=$ Agree, $\mathrm{SA}=$ strongly disagree

Frequency distribution of attitude by item showed in(table number -4) $41 \%$ of the respondents agree with the sentence that is important for my food health to eat 2 meals a day without skipping particularly, trying to make conscious effort to try drinking milk gained the highest the strongly agree at $52 \%$, while $24 \%$ strongly disagree with the fast food like fried chicken is good to eat every day and $36 \%$ disagree with this statement. And also 24 strongly disagree with the eating health is just another fashion.

Table-5 Frequency distribution of students' Attitude Level

\begin{tabular}{|c|c|c|c|c|c|c|}
\hline Attitude Level & \multicolumn{2}{|c|}{ Male } & \multicolumn{2}{c|}{ Female } & \multicolumn{2}{c|}{ Total } \\
\hline $\begin{array}{c}\text { Attitude about } \\
\text { health Nutrition }\end{array}$ & \multicolumn{2}{|c|}{$(\mathrm{n}=50)$} & \multicolumn{2}{c|}{$(\mathrm{n}=50)$} & \multicolumn{2}{c|}{$(\mathrm{n}=100)$} \\
\cline { 2 - 7 } & $\mathrm{n}$ & $\%$ & $\mathrm{n}$ & 19 & 38 & 38 \\
\hline Good (>80\%) & 19 & 19 & 19 & 19 & 48 & 48 \\
\hline Fair (60\% to 80\%) & 29 & 29 & 19 & 19 & 14 & 14 \\
\hline Poor (<60\%) & 2 & 2 & 12 & 12 & & \\
\hline
\end{tabular}


The above table revealed the level of attitude. Good level of attitude was found among $38 \%$ of the respondents, fair level and poor level were $48 \%$ and $14 \%$ respectively. The mean score was 74.80 , while standard deviation of 13.59 and the minimum score was 50 and maximum score was 96 among the total of respondents.

\section{Description of Nutritional Status:}

Nutritional status of students was determined by measuring weight for height $\left(\mathrm{kg} / \mathrm{m}^{2}\right)$. According to weight for height it will ordering with Body Mass Index for children Percentile and it was categorize by Underweight ( $\leq 5$ percentiles curve from chart), Healthy weight / Normal ( $>5$ to 85 percentiles curve from growth chart), at risk overweight ( $>85$ to 95 percentiles curve from growth chart), and Over weights ( $>95$ percentiles curve from growth chart). ${ }^{\mathrm{x}}$

Table-6 Frequency distribution of nutrition status between Male \& Female:

\begin{tabular}{|c|c|c|c|c|c|}
\hline \multirow[t]{2}{*}{ Nutritional Status } & \multicolumn{2}{|c|}{ Male } & \multicolumn{2}{|c|}{ Female } & \multirow{2}{*}{$\begin{array}{l}\text { Total } \\
\mathrm{n}=100\end{array}$} \\
\hline & $\mathrm{n}=50$ & $\%$ & $\mathrm{n}=50$ & $\%$ & \\
\hline Underweight & 12 & 12 & 11 & 11 & 23 \\
\hline Health weight & 30 & 30 & 31 & 31 & 61 \\
\hline At risk overweight & 6 & 6 & 6 & 6 & 12 \\
\hline Overweight & 2 & 2 & 1 & 1 & 3 \\
\hline \multicolumn{6}{|c|}{ Mean $=35.99, \mathrm{SD}=15.882$} \\
\hline
\end{tabular}

Regarding the classification of nutritional status, most of respondent ( $61 \% 0$ had health weight. This applied to both male and female $30 \%$ and $31 \%$ respectively. Some of them underweight $(23 \%)$ and overweight at risk $(6 \%)$ while others overweight $(2 \% \& 1 \%)$ respectively.

\section{Conclusion:}

This study was conduct to determine nutritional status among elementary school children in educational zone of Bandipora district, Kashmir region in state of Jammu \& Kashmir, a cross sectional study was conduct. The main purposes of research were to identify nutritional status and related factor among elementary school of Hajin educational zone. The data collection was achieved by interview schedule.

Research progressively supports the significant relation between nutrition and academic achievement. Healthy eating is essential for students to achieve their full academic potential, mental growth, and lifelong health and well-being. When children are not receiving proper nutrition they are impotent to reach their full potential. Schools must need to educate parents and children on how to live a healthy life that includes proper nutrition. Schools can help school-aged children develop healthy eating habits by emitting a consistent health message by ensuring that healthy food choices are offered at school. School administrators need to provide opportunities for staffs to receive education on good nutrition and health in the school environment. 
A school is an institution of education and research supports the role nutrition plays in education. This relationship supports the idea that schools have a vital role in providing students Nourishment and Educational Performance with healthy eating opportunities and the tools to make healthy choices no matter where they are. Intense pressure has been placed on schools to have students demonstrate high performance on state instructed test and nutrition plays a vital role in this success.

The variable of the study were predisposing factor (socio demographic factor included Grade of class, Gender, Age, Birth order, Knowledge and attitude towards the health nutrition and attitude towards nutrition)

It is observe that among the student in elementary school, the problem of underweight $\%$. This applies to both male and female $2 \%$ and $1 \%$ respectively, and overweight $3 \%$, this problem should not be overlooked and counter measure an expected to be developed.

It is also observed that concerning about association between $\mathrm{n}$ nutritional status and independent variable. We have also found some of the variables have significant association with nutritional status.

\section{Suggestions: for program implication;}

$\checkmark \quad$ To avoid students snacking in the school time, it is better to let them bring the food from home.

$\checkmark$ Periodical nursing and evaluation of nutritional status of the students should focus on underweight students.

$\checkmark$ Supplementary care from school is still need of the hour.

$\checkmark$ School nourishing programs should combine learning and teaching activities.

$\checkmark$ At last but not least; Health and nutrition should be done using teaching materials such promote by TV with interesting educational content, mass media and other devices that could help the student to easily understand the stuff.

\section{Test of hypothesis:}

$\mathrm{H}_{\mathrm{o}}$ : There is significant relationship between health and nutrition with academic potential and mental growth.

\section{Result: Supported.}

$\mathrm{H}_{\mathrm{o}}$ : Elementary Schooling plays a vital role in good health habits and nutritional food.

Result: Supported.

'WHO, (1997) "Primary School Physical Environment \& Health," WHO Global School Health Initiative. Who Information series on school health. Document Two. WHO, SIDA,

${ }^{i i}$ http://kidshealth.org/en/parents/overweight-obesity.html

iii Isaranurug, S. (1999) "Child and adolescent health promotion and protection in congested area of Bangkok mettroplis"; Watmakok community, Bangkok: Mahidol University: p-101.

iv Nelson WE (1996) “ Behman RE. Kliegman RM. Arvir AM., Editors' textbook of pediatric $15^{\text {th }}$ ed. Philadelphia. WB Saunders, p56-72.

"Public Health Service.(2000) "Healthy people 2000: national health promotion and disease prevention objectives". Full report, with commentary. Washington, DC: US Department of Health and Human Services, Public Health Service, 1991. DHHS publication no. (PHS) 91-50212.

vi Mandell RJ, ed. (1993) "The strategic plan for nutrition education: promoting healthy eating habits for our children". Washington, DC: US Department of Agriculture, Food and Nutrition Service, Nutrition and Technical Services Division. 


\footnotetext{
vii National Education Goals Panel. (1992)“The national educational goals report: building a nation of learners". Washington, DC: US Department of Education, National Education Goals Panel,.

viii Guroo, Tariq. Ah. (2017) The Roadmap of Poverty Alleviation (With special reference to Urban Local Bodies of Kashmir Valley), in Indian Society: Issues, Problems and Challenges, Artharva Publication, Aurangabad-431004, 27 Feb. p-2.

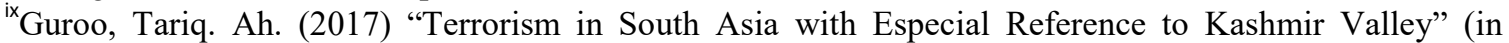
edition of India's Extended Neighbourhood by S.M. Waagh) Publisher Mr.Yuvraj Mali, Artharva Publication, jan.Dhule, Jan.6, 2017, p-119.

(Sources: World Health Organisation (2007). Error! Main Document Only.)
}

\section{References:}

[1] Deb S, Dutta S,etal. (2010). Relationship of Personal Hygiene with Nutrition and Morbidity Profile: A Study among Primary School Children in South Kolkata. Indian Journal of Community Medicine., 35(2), 280-284.

[2] Dongre AR, D. P. (2007). An approach to hygiene education among rural Indian school going children. . Online J Health Allied Sci, 6: 2.

[3] Feigelman, s. (2011). Middle childhood. In: Kliegman RM, Behrman RE, Jenson HB, Stanton BF. (N. T. Philadelphia, Ed.) Philadelphia: Pa: Saunders Elsevier.

[4] Lawrence, W. R. (1895). The Valley of Kashmir. Srinagar, J \& K: Gulshan Books.

[5] Lindberg L, Swanberg I. (2006). Well-being of 12-year-old children related to interpersonal relations, health habits and mental distress. 20:. Scand J Caring Sci.

[6] Luby SP, A. M. (2005). Effect of handwashing on child health: a randomised controlled trial. (Vol. 366). Lancet.

[7] M., S. ( 2013). Personal hygiene among primary school children living in a slum of Kolkata, India. . Journal of Preventive Medicine and Hygiene., 3(54), 153-158.

[8] Murray CJL, Lopez AD. . (1996.). The Global Burden of Disease: A Comprehensive Assessment of Mortality and Disability from Diseases, Injuries, and Risk Factors in 1990 and Projected to 2020. Cambridge: Harvard University Press.

[9] Nations, U. (2014). The UN convention on the rights of the child. Geneva: Office of the High Commissioner for Human Rights, 1989. Retrieved September 4th, 2014, from . [Cited 2012 Jul 09]. Available from: URL: http://www2.ohchr.org/english/law/ accessed.

[10] R.B., V. (2008.). School Health Services in India. The social and economic context. India: Sage Publications Pvt. Ltd.

[11] Rasool, H. (2012). Importance of Personal Hygiene. Importance of Personal Hygiene., 2153-2435. Pharmaceut Anal Acta.

[12] Vivas A, G. B. (2010). Knowledge, Attitudes, and Practices (KAP) of Hygiene among School Children in Angolela, Ethiopia.. Angolela: J Prev Med Hyg.

[13] Water and Sanitation Program Can hygiene be cool and fun: Insights from School Children in Senegal. . (n.d.). Retrieved June 14, 2016]., from Available at: http://www.comminit.com/en/node/264152/38. .

[14] Winchell, M. (2009). Eating Democracy and Corn Puppies. Reviews in American History, doi: 10.1353/rah.0.0076. (Vol. 37). American.

[15] Zullig et al. (2005). Adolescent health-related quality of life and perceived satisfaction with life. . London: Qual Life Res. 